\title{
THE INFLUENCE OF BUREAUCRATIC PATHOLOGY ON EMPLOYEE PERFORMANCE IN E-KTP SERVERS IN THE DEPARTMENT OF POPULATION AND CIVIL REGISTRATION OF BANDUNG CITY
}

\author{
Aswin Palls \\ Public Administration Study Program, Faculty of Social and Political Sciences, \\ Pasundan University \\ aswin.palls@unpas@ac.id
}

\begin{abstract}
The pathology of the bureaucracy is a disease in the state bureaucracy that arises due to the behaviour of the bureaucrats and the conditions that open up opportunities for it, whether related to politics, economics, social culture and technology. The role of the bureaucracy as the implementer of political policy, or in other words the bureaucracy as the organizer of the government, then the pathology of the bureaucracy can be interpreted as a problem or problem that occurs in government administration due to the inability of the bureaucracy's performance to meet public needs properly. The pathology of the bureaucracy can be manifested in the inability of political officials in the executive (elected due to political mandates) or the performance problems of elected public officials, namely officials in the bureaucracy who occupy positions due to the political process. Or because of the performance of administrative leaders, namely career bureaucrats who occupy career positions in the bureaucracy. Or the bureaucracy itself as an institution, or government agents or bureaucrats who are unable to provide public satisfaction. With the emergence of bureaucratic disease in the organizational structure, it has become a major influence in service. In addition, there is still discrimination in services or differences in services including the E-KTP making service provided by officers to the community. The level of response or staff skills which is still low, needs to be improved and is important in influencing the level of community satisfaction where the service is fair and regardless of status and position supported by the availability of adequate facilities and infrastructure in administrative services.
\end{abstract}

\section{Keywords: Pathology, Bureaucracy, Performance, Service}

\section{Introduction}

The pathology of the bureaucracy is a disease in the state bureaucracy that arises due to the behavior of the bureaucrats and the conditions that open up opportunities for it, whether related to politics, economics, socio-cultural and technological. Bureaucratic pathology or bureaucratic disease is the "result the interaction between the wrong bureaucratic structure and the wrong environmental variables". The pathology of bureaucracy arises because the relationships between variables in the bureaucratic structure are too excessive, such as hierarchical chains length, specialization, formalization and performance of the bureaucracy are not linear.

Pathology of bureaucracy can be manifested in the inability of political officials in the executive (elected because of political mandates). In this case, the pathology of the bureaucracy can be seen from an institutional perspective, political leadership in the executive, the behavior of the bureaucratic elite and the behavior of the bureaucrats themselves (Pathology Bureaucracy, 2009).

Bureaucracy is a clearly defined hierarchy in which office holders have very specific functions and apply or apply universal rules in a spirit of impersonality and formalism. Bureaucracy is a system of administration and implementation of daily tasks that are structured in a clear hierarchical system, carried out with written rules carried out by certain sections that are separated from other 
parts by people or staff according to their expertise. (Bureaucracy, 1978).

To manage change, organizations need to adapt the mindset, culture and attitudes of people to the new environment, so that with an effective and efficient bureaucracy, good governance is created.

Performance is the result of work in quality and quantity that can be achieved by an employee in carrying out tasks in accordance with the responsibilities assigned to him. Based on the opinion of several experts, it can be concluded that the assessment of work performance (performance) is an assessment that is carried out systematically to determine the results of employee work and organizational performance.

As a system engaged in the implementation of public organizations, the bureaucracy has a very important role in the implementation of the organization. Therefore, the government must be more careful in implementing the organization in order to reduce or prevent the existence of bureaucratic pathologies or diseases.

In the implementation of the bureaucracy, two aspects need to be considered, namely aspects of change and aspects of people. Change cannot be forced, but done by means of adaptation.

\section{Method}

In this writing method, the data source used by the author to obtain data is literature research, namely by studying the problems from the literature and other data sources related to the problem of writing this journal.

This writing is a descriptive study. Descriptive research has the characteristics of focusing on current actual problems. The data that has been collected is then compiled, analyzed, explained and concluded.

The data we get can be searched from books, journals, research report articles, and web sites on the internet.

\section{Data Collection Technique.}

According to M. Nazir in his book entitled "Research Methods" suggests that what is meant by: "Literature study is a data collection technique by conducting study studies of literature books, notes, and reports related to the problem. that is solved. Nazir, (2013)

Literature study is conducting research by studying and reading literatures that have to do with the problems that are the object of research.

\section{Result and Discussion}

The preamble to the 1945 Constitution of the Republic of Indonesia mandates that the objectives of the establishment of the Republic of Indonesia are, among other things, to promote general welfare and the intellectual life of the nation.

This mandate implies that the State is obliged to fulfill the obligations of every citizen through a government system that supports the creation of prime public services in order to fulfill the basic needs and civil rights of every citizen for public goods, public services and administrative services.

The bureaucracy is an important instrument in a society whose presence cannot be avoided. Bureaucracy is a syllogical consequence of the acceptance of the hypothesis that the State has a sacred mission, namely to prosper its people.

For this reason, the State builds an administrative system that aims to serve the interests of its people as mandated in accordance with Article 1 Paragraph (1) of Law Number 25 of 2009 concerning Public Services. (Law Number 25 of 2009, 2009) It is stated that Public Service is an activity or series in order to fulfill service needs in accordance with statutory regulations for every citizen and resident for goods, services, and or administrative services provided by public service providers. . Based on this definition, the fulfillment of public service activities has been regulated based on regulations made by the government with the main objective of meeting basic needs and welfare of the community.

However, with the existence of administrative service problems that greatly affect the running of the bureaucracy, this problem is what is called pathology or disease in the bureaucracy. 
The pathology of bureaucracy is a disease in the state bureaucracy that arises due to the behavior of the bureaucrats and the conditions that open up opportunities for it, whether related to politics, economics, social culture and technology.

Pathology of bureaucracy can be manifested in the inability of political officials in the executive (elected because of political mandates). In this case, the pathology of the bureaucracy can be seen from an institutional perspective, political leadership in the executive, the behavior of the bureaucratic elite and the behavior of the bureaucrats themselves (Pathology Bureaucracy, 2009)

According to the author's analysis, the bureaucracy will run well if a political official in the executive can carry out his job according to his abilities or what is often called "The Right Man and The Right Place" and carry out the implementation of the bureaucracy in a transparent manner.

The various pathologies of the bureaucracy include:

1. Paternalistic, namely the superior is like a king who must be obeyed and respected, treated specially, there is no strict control, and subordinate employees do not have the determination to criticize whatever the superior has done. This makes public service less than optimal due to the excessive attitude of subordinates towards superiors so that the bureaucracy tends to ignore what is in the interests of society as citizens who are obliged to receive the best possible service;

2. Budget swelling, there are several reasons why this often happens, namely: the greater the budget allocated for activities the greater the opportunity to mark-up the budget, there is no clarity between costs and revenues in the public bureaucracy, there is a tradition of cutting the proposed budget. In the budget planning process, thus giving rise to initiatives for those who submit budgets to exaggerate budgets, and the tendency of the bureaucracy to allocate budgets on the basis of input. The budget swelling will widen when the power of civil society is weak in controlling the government;

3. Excessive procedures will result in convoluted services and be less profitable for the community when in an urgent situation;

4. Swelling of the bureaucracy can be done by increasing the number of structures in the bureaucracy on the grounds of reducing the workload and others whose existence is not really necessary. As a result, a lot of APBN (State Revenue and Expenditure Budget) funds are issued by the government which can indirectly harm the State. So that the budget is not on target; and

5. Fragmentation of the bureaucracy, the number of new ministries created by the government is more often than not based on a need to respond to the interests of the community so that it is more accommodated but rather on certain motives

6. Service is helping to provide everything that is needed by other people, including the buyer. Service can be given to others as the help others need themselves. This with this help can help others to overcome the problem.

7. Moenir (2005: 47). (2005) He explained that service is a process of meeting needs directly through other people's activities.

\section{Troubleshooting the Pathology of Bureaucracy}

Seeing the many diseases inherent in the bureaucracy, therefore it is necessary to have a countermeasure to improve the bureaucracy so that it is better, responsive and able to respond to what is in the public interest. Several things need to be done in order to overcome bureaucracy or other languages to cure chronic diseases inherent in the bureaucracy, namely, develop a holistic (comprehensive) bureaucratic development policy so that it is able to touch all dimensions, be it system, structure, culture, and bureaucratic behavior, develop a democratic political system capable of controlling the running of government with the intention of making the government more transparent, responsible for what they do and the public with easy access to public information; developing information and communication technology-based bureaucracies such as e-government to facilitate interaction between the community and service providers.

According to the author's analysis, one of the pathologies of the bureaucracy in the E-KTP service, one of which is extortion (Pungli) 
carried out by irresponsible public officials. The phenomenon of bribery or illegal fees in public services is still widely encountered in various types of services in districts and cities. There are many factors that cause illegal levies in the bureaucracy to become a common phenomenon in public service practices in Indonesia. Apart from the low income of the bureaucratic apparatus, illegal levies occur because the bureaucratic structure is still very dominant in the practice of providing public services.

As in the management of E-KTP in all subdistricts in Indonesia, which is free of current administration fees, it makes the community's desire very high to immediately take care of and get the E-KTP. However, in managing the E-KTP, there were still weaknesses in the field carried out by officers. This weakness, among others, is the occurrence of illegal levies made by officers making E-KTPs.

One of the causes of the poor performance of public services is the complex (fat) structure of the public service bureaucracy. So far, a public service bureaucracy often does not have sufficient authority to individually complete the public service process in its institution.

So to create performance, good public service must be in the presence of a service structure that is not too broad in terms of organizational structure, but creates an organizational structure that is effective, efficient and in accordance with Standard Operating Procedures (SOP).

Pathological symptoms in the bureaucratic system have long existed in the Indonesian government. Various forms of pathology and various causes can basically be identified, but the solution to deal with them is not an easy thing, has been in Indonesian government for a long time. Various forms of pathology and various causes can basically be identified, but the solution to deal with them is not an easy thing.

\section{Implementation of Effective Ethical Standards.}

One of the steps to eradicate pathology in the bureaucracy is to improve employee integrity.To improve integrity, there are three things that need to be considered. First, identify threats to integrity in the bureaucracy. If threats can be identified, anticipatory steps can be taken. Second, strengthen employee ethical competences and professional ethics support mechanisms. There needs to be new ways for the government to implement a culture of bureaucratic ethics that is clean and serves to be implemented, especially regarding civil servant discipline, responsibility for carrying out duties and complying with applicable regulations.

The ethical standards referred to are divided into several discussions as follows.

1. Code of Ethics and Code of Conduct.

Code of ethics can be interpreted as core values to shape professional employee behavior. Code of ethics usually contains the values of integrity, accountability, responsibility, trustworthiness.

\section{Service Standards}

To reform the bureaucracy in the mental change area of the apparatus, generally set service standards that consider aspects of service and accountability to complement employee ethics and behavior.

\section{Maladministration}

Efforts to change the mental apparatus in the bureaucracy, especially in relation to the eradication of extortion practices, also need to see the concept of maladministration. explained in Article 3 which contains Maladministration is behavior or actions against the law, beyond authority, using authority for purposes other than those of the said authority, including negligence or neglect of legal obligations in the administration of public services carried out by State Administrators and governments that cause material and / or immaterial losses for society and individuals. Law Number 37 of 2008 concerning the Ombudsman of the Republic of Indonesia. (Law Number 37 of 2008, 2008)

\section{Public Information Disclosure}

The government needs to give the community the right to obtain information about various decisions and actions taken.

\section{Community Responsibility}

The community needs to be encouraged to stay away from behavior that can influence employees to commit acts of violations such as extortion. The public is also expected to report employees who commit violations. 


\section{Conclusion}

It can be concluded that Bureaucratic Pathology is a disease within the organization that is very detrimental and disrupts the activities of the bureaucracy. This bureaucratic disease not only endangers humans in the organization, but also endangers all people who take part in receiving services.

In addition, bureaucratic pathology can cause various negative influences on employees who carry out illegal fees, this impact can be a bad influence because when someone is satisfied and gets a beneficial effect from these activities, someone's dissatisfied behavior appears and becomes dependent on these actions and ended up hurting many people.

The efforts made by government officials in providing cultural services with a friendly attitude that is government-oriented as a provider for the needs of the community as users need to be further improved and important in influencing the level of community satisfaction where services are evenly distributed and without differentiating status, the position where supported are available facilities. and adequate infrastructure in making E-KTP services.

The pathology of bureaucracy must be treated with rules, systems and management commitments that are oriented to serve, not to be served, to encourage, not inhibit, facilitate, not complicate, simple, not complicated, open to everyone, not just a handful of people.

\section{Acknowledgments}

To get a healthy bureaucracy or away from bureaucratic pathology is not easy. With this it is necessary to improve administrative services by running / conducting open recruitment of officers who are trustworthy, honest, and responsible for the assigned tasks, so as to provide good, professional and transparent services.

The population and civil registration office of the city of Bandung appealed to the public to provide complaints or suggestions on the services provided through the website or letters provided by the population and civil registration service. This is intended so that employees can evaluate deficiencies and can improve service quality.

\section{References}

(2005). In Moenir.

(2008). Retrieved from Law Number 37 Year 2008: file: /// G: / TUGAS\%20JURNAL\%20BIROKRAS I/pdf/UU_2008_37.pdf

(2009). In Ismail, Pathology of Bureaucracy (p. 69).

(2013). In Nazir.

Bureaucracy. (1978). In Rourke.

Bureaucratic Pathology. (2009). In Ismail.

Law Number 25. (2009). In Public Services (p. Article 1 Paragraph 1).

:http://thepublicadministration.blogspot.com /2012/11/patologi-birokrasi.html

https://definisimu.blogspot.com/2012/08/def inisi-kinerja.html

https://www.seputarpengetahuan.co.id/2016/ 10/pengertian-pelayanan-menurut-paraahli-lengkap.html

file://G:/TUGAS\%20JURNAL\%20BIROK RASI/pdf/14462-46323-1-PB.pdf 